\title{
LETTER:
}

\section{CAVEAT: PITFALLS IN THE MEASUREMENT OF PH OF DRIP WATERS IN CAVES}

\section{CAVEAT: PROBLEMATIKA MERITEV PH V PRENIKLIH VODAH KRAŠKIH JAM}

\author{
Wolfgang DREYBRODT
}

UDK: 551.444:66-915

\section{INTRODUCTION}

Instrumental cave monitoring has become an important concept to understand climate proxy archives stored in speleothems. Many studies to measure hydrochemical data of drip waters, the isotopic composition of drip water carbonates, and cave climatic parameters, such as temperature, humidity and $\mathrm{P}_{\mathrm{CO}_{2}}$ have been performed during the last decade (PAGES News, 2008). Many new projects are in progress in various caves worldwide, e. g. Bunker cave in Germany and Grotta di Ernesto, NE Italy (Riechelmann et al., 2011, Miorandi et al., 2010). An important parameter in the hydrochemistry of drip waters is $\mathrm{pH}$, because it is a master variable determining supersaturation $\mathrm{SI}_{\mathrm{C}}$, which controls calcite precipitation rates on speleothems.

To measure $\mathrm{pH}$ drip water samples are collected in glass flasks until a sufficient amount of water is available to measure $\mathrm{pH}$ with suitable electrodes. Depending on drip rate the time to collect the sample ranges between few minutes (e. g. $10 \mathrm{drops} / \mathrm{min}$ ) to hours for drip rates less than $1 \mathrm{drop} / \mathrm{min}$. During this time the sample in the sample container stays as a layer with increasing depth $\delta$. $\mathrm{CO}_{2}$ contained in the solution degasses from this layer with an exponential time constant $\mathrm{T}=4 \cdot \delta^{2} / \pi^{2} \cdot \mathrm{D}_{\mathrm{m}}$, where $\mathrm{D}_{\mathrm{m}}$ is molecular diffusivity of the $\mathrm{CO}_{2}$ - molecules in the solution. $\mathrm{D}_{\mathrm{m}}$ depends on temperature by the relation $\mathrm{D}_{\mathrm{m}}=5.6 \cdot 10^{-6}+5.8 \cdot 10^{-7} \mathrm{~T}_{\mathrm{c}}\left(\mathrm{cm}^{2} \mathrm{~s}^{-1}\right)$, where $\mathrm{T}_{\mathrm{c}}$ is in ${ }^{\circ} \mathrm{C}$ (Dreybrodt and Scholz, 2011, Dreybrodt, 2011). After the time, $\mathrm{T}_{\text {out }}=3 \mathrm{~T}, 95 \%$ of the aqueous $\mathrm{CO}_{2}$ has degassed from the water. For a water layer of depth $\delta=0.2 \mathrm{~cm}$ the time $\mathrm{T}_{\text {out }}$ of outgassing is $40 \mathrm{~min}$.

Equilibration of the carbonate ions and $\mathrm{pH}$ with the reduced concentration of aqueous $\mathrm{CO}_{2}$ needs several minutes (Dreybrodt and Scholz, 2011, Dreybrodt, 2011). Therefore $\mathrm{pH}$ in the solution increases with time.

In this letter we demonstrate this in a simple experiment. From a column of solution $\mathrm{CO}_{2}$ degasses in time scales much longer than equilibration time with respect to $\mathrm{pH}$. In this case the $\mathrm{pH}$ change is controlled by $\mathrm{CO}_{2}$ outgassing and proceeds with the time constant $\mathrm{T}$. 


\section{THE EXPERIMENT}

Fig. 1 shows the simple experimental set up consisting of small plastic beakers. They are filled with mineral water from the Harzquelle, Bad Harzburg, which contains $93.9 \mathrm{mg} / \mathrm{L}$ of Ca, $18.7 \mathrm{mg} / \mathrm{L}$ of $\mathrm{Mg}$, and $254 \mathrm{mg} / \mathrm{L}$ of hydrogen carbonate, sulfate $75,2 \mathrm{mg} / \mathrm{L}$, and also minor amounts of $\mathrm{Na}(11.7 \mathrm{mg} / \mathrm{L}), \mathrm{Cl}(25.9 \mathrm{mg} / \mathrm{L})$, and $\mathrm{K}(1.23 \mathrm{mg} / \mathrm{L})$. The water has been shaken rigidly in its bottle to remove most of the $\mathrm{CO}_{2}$ from the water until no further bubbles occurred. This warrants that $\mathrm{P}_{\mathrm{CO} 2}$ in the water is below $1 \mathrm{~atm}$ and bubbles cannot form any more. The $\mathrm{pH}$ of the water was then about $5.1 \mathrm{~cm}^{3}$ of this water was added to the first beaker, $2 \mathrm{~cm}^{3}$ to the second and 3 $\mathrm{cm}^{3}$ to the third. This corresponds to a depth of the water layer of $0.22 \mathrm{~cm}, 0.44 \mathrm{~cm}$, and $0.66 \mathrm{~cm}$, respectively. Temperature is $20^{\circ} \mathrm{C}$. Outgassing proceeds into the open atmosphere.To monitor the evolution of $\mathrm{pH}$ the fluid $\mathrm{pH}$-indicator solution Merck $\mathrm{pH}-1$ was mixed to the water, such that its concentration was equal in all three beakers. The color of the solution changes from red at $\mathrm{pH}=5$ to green-blue at $\mathrm{pH}=9$.

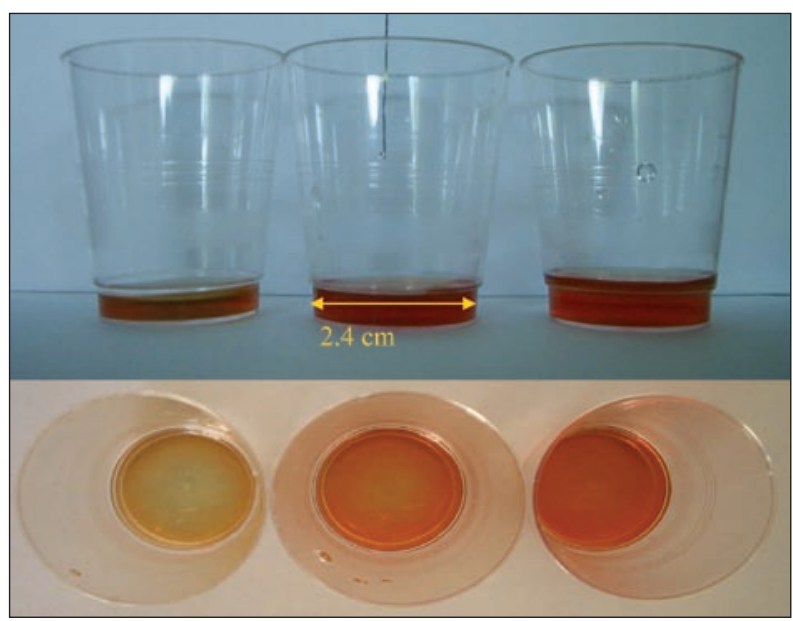

Fig. 1. Three plastic beakers with plain bottom contain an initially identical $\mathrm{CaCO}_{3}-\mathrm{CO}_{2}-\mathrm{H}_{2} \mathrm{O}$ solution. But the depth of the water layers is $0.22 \mathrm{~cm}, 044 \mathrm{~cm}$, and $0.66 \mathrm{~cm}$ respectively.

Photos from this set up were taken during a time course of 7 hours. Fig. 2 shows how the colors in the three beakers change in time. The color code at the left relates $\mathrm{pH}$ to color of the indicator solution Merck $\mathrm{pH}-1$.

The first row with the beaker with a depth of $0.22 \mathrm{~cm}$ shows a rapid change in color from orange to green after $40 \mathrm{~min}$, indicating a change of $\mathrm{pH}$ from about 5.8 to about 8 , as can be seen by comparison to the color code of the $\mathrm{pH}$-indicator at the left hand side. For the beaker in the second row with a depth of $0.44 \mathrm{~cm} \mathrm{pH}$ of about 8 is reached after $153 \mathrm{~min}$, whereas the water in the third row with depth of $0.66 \mathrm{~cm}$ needs about $420 \mathrm{~min}$. This is only a crude estimation by comparison of colors, but it shows clearly that after a sample has been collected $\mathrm{pH}$ changes considerably.

Theoretically the times needed for a given shift of $\mathrm{pH}$ depend on $\delta^{2}$. That means the ratio from the thin layer of $0.22 \mathrm{~cm}$, to that of 0.44 and $0.66 \mathrm{~cm}$ should be $\mathrm{T}_{0.22}: \mathrm{T}_{0.44}: \mathrm{T}_{0.66}=1: 4: 9$. The ratio estimated from the color changes is $1: 3.8: 10.5$. Regarding the crudeness of the experimental estimation this can be regarded as satisfactory.

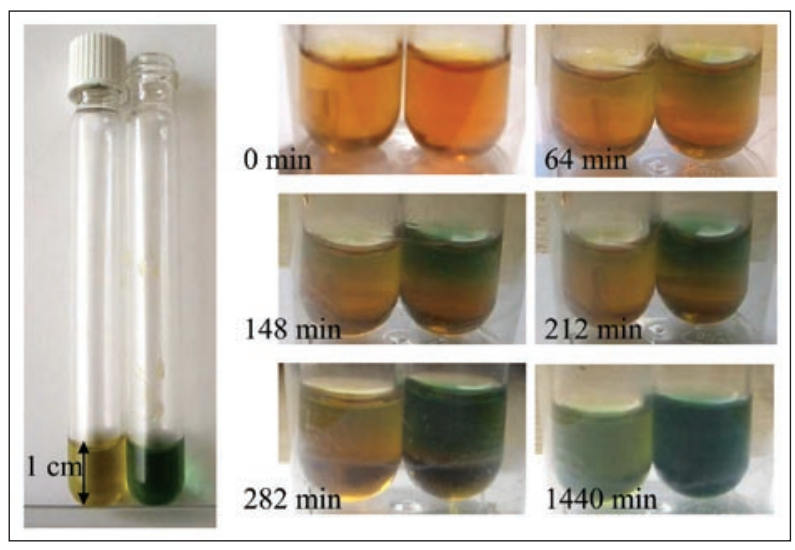

Fig. 3. Evolution of $p H$ when complete outgassing is prevented by limited headspace in the bottle covered by a lid.

In summary the experiment visualizes convincingly that after sample collection the $\mathrm{pH}$-values of drip waters change in time. Only when $\mathrm{pH}$ is measured immediately after collection the value is reliable.

To take reliable data from slowly dripping sites one has to measure from small volumes corresponding to only 1 drop of about $0.1 \mathrm{ml}$. This is possible with the Micro pH Probe of Lazarlab, PHR-146 Micro Combination $\mathrm{pH}$ electrode (www.lazarlab.com/microph.htm).

To give further evidence that outgassing of $\mathrm{CO}_{2}$ controls $\mathrm{pH}$ in our experiment, we have compared the evolution of $\mathrm{pH}$ in two bottles, one with open space to the atmosphere and the other with restricted headspace by covering the bottle with a lid. In the beginning both bottles are filled by $1 \mathrm{~cm}^{3}$ of identical solution of the mineral water with $\mathrm{pH}$ at about 6 . This is shown in Fig. 3a. Fig. $3 \mathrm{~b}$ shows the change of color in time. Final $\mathrm{pH}$ of about 8.5 (dark blue in the right bottle) is reached after about $1440 \mathrm{~min}$. This corresponds to a time of $4 \mathrm{~T}$. The left bottle covered by a lid attains a lower $\mathrm{pH}$, which remains stable for several days. Photo $3 a$ has been taken 2 days later. The reason is that the $\mathrm{CO}_{2}$, which has degassed from the fluid is trapped in the headspace and $\mathrm{P}_{\mathrm{CO} 2}$ in the open bottle is lower than in the one covered. 


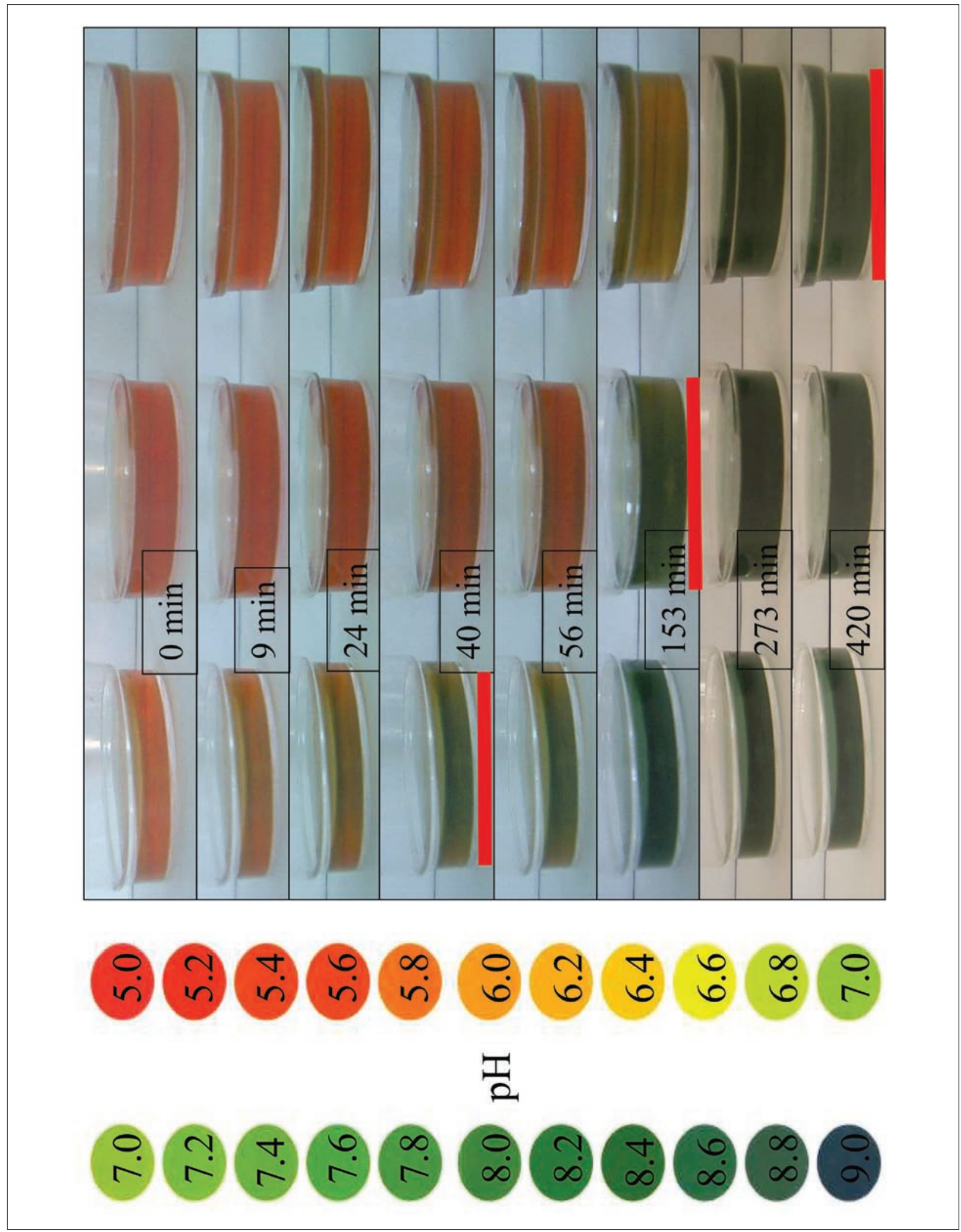

Fig. 2. Change of color in beakers with different layer depth, from left to right, $0.22 \mathrm{~cm}, 0.44 \mathrm{~cm}, 0.66 \mathrm{~cm}$. The beakers underlined in red show similar colors and consequently exhibit similar $\mathrm{pH}$-values of the water. Circles on the left show the $\mathrm{pH}$-color relation of the indicator solution. 


\section{CONCLUSION}

Measurements of $\mathrm{pH}$ of drip waters in caves must be performed immediately after collection.. Collecting samples, especially at low drip rates, and performing measurements hours or even days later will give higher $\mathrm{pH}$-values than those in the initial drip water. This is true for drip waters that have a $\mathrm{PCO}_{2}$ larger than that in the cave atmosphere. If the drip is formed by water flowing in thin $(\delta<0.03 \mathrm{~cm})$ films slowly towards the drip point there is sufficient time for outgassing, and $\mathrm{PCO}_{2}$ and $\mathrm{pH}$ are close to equilibrium with the cave atmosphere when the drop falls. In this case $\mathrm{pH}$ will change only slightly even hours after sampling.

\section{REFERENCES}

Dreybrodt, W., 2011: Letter: Comments on processes contributing to the isotope composition of ${ }^{13} \mathrm{C}$ and ${ }^{18} \mathrm{O}$ of calcite deposited in the calcite of speleothems.- Acta Carsologica, 40, 2, 233-238.

Dreybrodt, W., D Scholz, D, 2011: Climatic dependence of stable carbon and oxygen isotope signals recorded in speleothems: From soil water to speleothem calcite.- Geochim.Cosmochim. Acta, 75, 734-752.

Miorandi, R., Borsato, A., Frisia, S., Fairchild, I. J. \& D.K. Richter, 2010: Epikarst hydrology and implications for stalagmite capture of climate changes at Grotta di Ernesto (NE Italy): results from long-term monitoring.- Hydrological Processes, 24, 3101-3114.
Riechelmann, D., Schröder-Ritzrau, A., Scholz, D., Fohlmeister, J., Spötl, C., Richter, D.K. \& A. Mangini, 2011: Monitoring Bunker Cave (NW Germany): A prerequisite to interpret geochemical proxy data of speleothems from this site.- Journal of Hydrology, 409,682-695.

Fleitmann, D., Spötl,C., Newman, L. \& T. Kiefer (eds.), 2008: Science Highlights: Advances in Speleothem Research.- Pages News, 16, 3. 